УДК 633.854.78:631.543:631.58 (477.7)

DOI https://doi.org/10.32848/agrar.innov.2021.10.7

\title{
НОРМА ВИСІВУ НАСІННЯ ЯК ФАКТОР ФОРМУВАННЯ ПРОДУКТИВНИХ ТА ГОСПОДАРСЬКО ЦІННИХ ОЗНАК ГІБРИДІВ СОНЯШНИКУ БАГАТОКВІТКОВОГО ЗА ОРГАНІЧНОЇ ТЕХНОЛОГІЇ ВИРОЩУВАННЯ В ПІВДЕННОМУ СТЕПУ
}

\author{
ЖУЙкОВ О.Г. - доктор сільськогосподарських наук, професор \\ https://orcid.org/0000-0002-5762-7934 \\ Херсонський державний аграрно-економічний університет \\ ЛАВРИСь В.Ю. - аспірантка III року навчання \\ https://orcid.org/0000-0002-5687-3412 \\ Херсонський державний аграрно-економічний університет
}

Постановка проблеми. Аналіз сучасного стану вітчизняного ринку рослинницької продукції дає можливість зробити висновок, що «флагманом» напряму технічних культур (а в окремих агрозонах - і взагалі провідною польовою культурою) в останні 15-18 років був і залишається соняшник [1]. Науково обґрунтовану межу насиченості польових сівозмін, що становить 10-12,5\%, перейдено давно і, на нашу думку, безповоротно. Отже, на перший план нині виходять проблеми, спричинені перенасиченістю агроценозів цією, треба визнати, високомаржинальною та технологічною культурою, а саме: усе більше погіршення агромеліоративного та фітосанітарного стану агроландшафтів, брак гарних попередників для озимих колосових культур тощо [2]. Не тішимо себе ілюзіями, що ситуація зміниться докорінно найближчим часом, проте вбачаємо за один із цілком реальних способів зменшення гостроти проблеми перегляд «професії» соняшнику, а саме розглядання його різновидів крізь призму отримання фітосировини лікарського призначення, що переводить процес вирощування культури на якісно новий рівень. У цьому аспекті, світова популярність, що зростає, багатоквіткового соняшнику саме як лікарської рослини оцінюється нами як цілком реальний шанс для вітчизняних аграріїв [3].

Аналіз останніх досліджень і публікацій свідчить про те, що культура багатоквіткового декоративного соняшнику як лікарської культури $є$ абсолютно новою для України, а ті поодинокі (і часто невдалі) спроби окремих суб'єктів господарювання отримати врожаї фітосировини здебільшого базуються на застосуванні досить емпіричних технологій, побудованих на фрагментарно залучених елементах зональних технологій соняшнику олійного [3; 4]. Водночас зазначена проблема $є$ абсолютною білою плямою і в науковому аспекті, систематичні дослідження вітчизняних науковців у даному напрямі не ведуться взагалі, а поодинокі намагання дослідників вивчити окремі елементи технології культури мають, радше, фррагментарний характер і не вирізняються системністю [2; 3]. Цей фракт, а також те, що попит на фітосировину (висушені пелюстки чоловічих квіток культури) за останні 5 років зріс на світовому ринку більш ніж удесятеро, зумовили і сфрормували тематику та проблематику наукового дослідження [4].

Метою наукового дослідження є проведення конкурсного випробування сучасного гібридного складу культури, його еколого-господарське обґрунтування, а також установлення оптимальної норми висіву. На вивчення були винесені такі елементи фенолого-біометричного та структурного характеру: тривалість вегетаційного періоду й окремих міжфазних періодів культури, висота рослин декоративного соняшнику, виживання рослин упродовж вегетації, кількість квітучих кошиків на рослині, діаметр кошика, маса пелюсток з одного суцвіття та з однієї рослини.

Матеріали та методика досліджень. Реалізацію поставленої наукової мети було здійснено закладанням і проведенням двофакторного польового досліду, у якому фрактором А виступав гібрид культури (Teddy F1, Double Sunking F1, Santa Fe F1), а фрактором B - норма висіву культури (50, 60 та 70 тисяч шт. схожих насінин на 1 га). Повторність у досліді чотирикратна, загальна площа дослідної ділянки становить 0,75 га, загальна площа ділянки першого порядку - $280 \mathrm{~m}^{2}$, облікова $250 \mathrm{~m}^{2}$. Ділянки в досліді розміщувалися методом розщеплених ділянок із частковою рендомізацією. Фенологічні спостереження проводили на постійно закріплених облікових площадках у двох несуміжних повтореннях. За початок фази приймали час її настання в $10 \%$, а за повну фазу - у $75 \%$ рослин. Обов'язково відмічали дати проходження основних фраз розвитку культури: сходи, I-III пари справжніх листків, утворення кошика, цвітіння. Густоту посіву визначали двічі за вегетацію на тих самих площадках, які виділили після сівби. Перший підрахунок проводили у фазу сходів, другий - у фразу цвітіння. Для визначення структури врожаю з кожного варіанта досліду відбирали по два модельні снопи, які містили типові для варіанта рослини, дослідження проводили у природно-вологому стані.

Результати досліджень. У результаті проведеного аналізу наведених нижче даних можна зробити висновок про об'єктивну відсутність залежності між тривалістю міжфазного періоду «сівба - сходи» культури від такого агроприйому, як проведення сівби з різними нормами висіву (табл. 1).

Отже, тривалість зазначеного міжфазного періоду, за яким можна робити оцінку щодо відповідності того чи іншого гібрида екологічним умовам зони вирощування (насамперед температури і вологості посівного шару ґрунту), залежала суто від генетичних особливостей конкретного гібрида соняшнику багатоквіткового. За цим показником у досліді істотно виділявся гібрид Teddy $\mathrm{F} 1$, тривалість утворення фрази повних сходів якого 
Меліорація, землеробство, рослинництво

Фенологічні показники гібридів соняшнику багатоквіткового залежно від норми висіву насіння

Таблиця 1

\begin{tabular}{|c|c|c|c|c|}
\hline \multirow{2}{*}{ Гібрид (фактор A) } & \multirow{2}{*}{$\begin{array}{c}\text { Норма висіву, тис. шт./га } \\
\text { (фактор B) }\end{array}$} & $\begin{array}{c}\text { Міжфазний період } \\
\text { «сівба - сходи» }\end{array}$ & Фаза цвітіння & $\begin{array}{c}\text { Загальний період } \\
\text { вегетації }\end{array}$ \\
\hline \multirow{3}{*}{ Teddy F1 } & 50 & 6 & 22 & 122 \\
\cline { 2 - 5 } & 60 & 6 & 19 & 118 \\
\cline { 2 - 5 } & 70 & 6 & 15 & 115 \\
\hline \multirow{3}{*}{ Double Sunking F1 } & 50 & 10 & 12 & 107 \\
\cline { 2 - 5 } & 60 & 10 & 9 & 102 \\
\hline \multirow{3}{*}{ Santa Fe F1 } & 70 & 10 & 10 & 114 \\
\cline { 2 - 5 } & 50 & 11 & 10 & 110 \\
\cline { 2 - 5 } & 60 & 11 & 7 & 105 \\
\hline
\end{tabular}

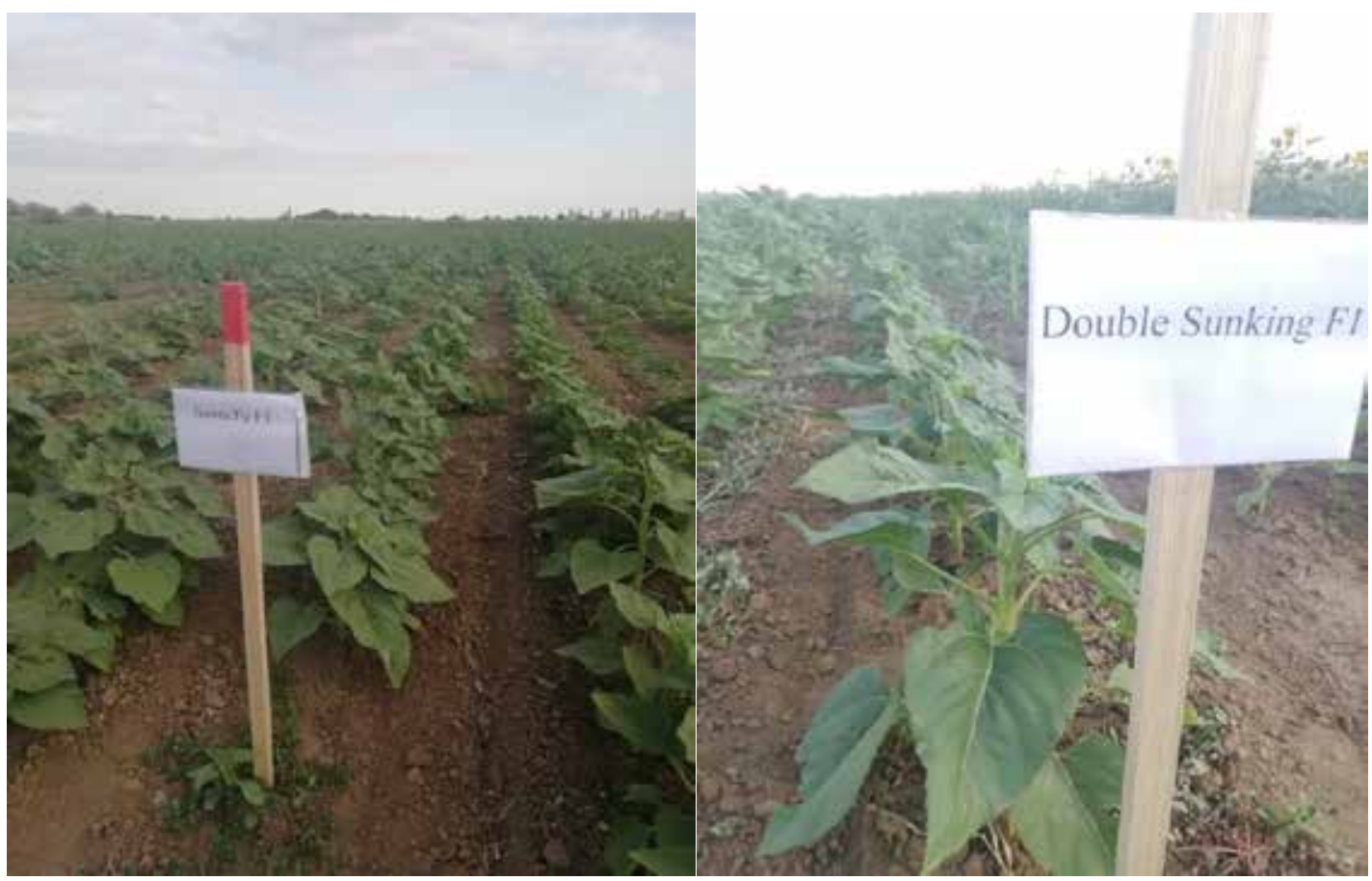

Рис. 1. Загальний вигляд дослідної ділянки

3 момента сівби була найменшою з-поміж інших варіантів чинника А і становила 6 діб, що на 4 та 5 діб відповідно менше, ніж у варіантах гібридів Double Sunking F1 та Santa Fe F1 (рис. 1).

Стосовно найбільш принципової в технології вирощування соняшнику багатоквіткового фрази росту і розвитку, яка саме зумовлює кількісно-якісні показники фітосировини, що вирощується (сушені пелюстки чоловічих квіток) - фази цвітіння, у досліді нами зазначена чітка залежність зменшення тривалості цієї фрази зі збільшенням загущеності посіву за всіма варіантами чинника А. Так, її максимальна тривалість була відмічена нами за варіантом гібрида Teddy F1 і становила в середньому 19 діб (від 22 діб за густоти 50 тис. шт./га до 15 діб за 70 тис. шт./га). Варіанти гібридів Double Sunking F1 та Santa Fe F1 істотно поступалися за даним показником і продемонстрували майже вдвічі коротшу тривалість зазначеної фенологічної фази (10-9 діб). Загалом, дані гібриди припинили вегетацію істотно раніше за гібрид Teddy F1, який вегетував у середньому 118 діб (122-115 діб залежно від загущення посіву): за варіантом гібрида Double Sunking F1 тривалість вегетації була 107-100 діб, а за гібридом Santa Fe F1 - 114-105 діб, скорочувалась із збільшенням норми висіву культури.

Стосовно показників структури врожаю культури, нами зроблений висновок про зворотний характер залежності показника кількості квітучих суцвіть на 1 рослині від норми висіву культури за всіма варіантами фактора А. Так, за варіантом гібрида Teddy F1 збільшення норми висіву від 50 до 70 тис. шт./га зумовлювало зменшення кількості квітучих кошиків із 3,4 до 2,6; за гібридом Double Sunking F1 - із 2,7 до 1,8; за гібридом Santa Fe F1 це зменшення було ще більш істотним і становило від 2,6 до 2,0 суцвіття на 1 рослині. Лідером у досліді за показником середньої маси кошика (у природно-вологому стані) був гібрид Teddy F1, маса суц- 
Структурні показники врожаю фітосировини гібридів соняшнику багатоквіткового залежно від норми висіву культури

\begin{tabular}{|c|c|c|c|c|c|c|}
\hline \multirow{2}{*}{ Гібрид (фактор A) } & $\begin{array}{c}\text { Норма висіву, } \\
\text { тис. шт./га } \\
\text { (рактор B) }\end{array}$ & $\begin{array}{c}\text { Кількість } \\
\text { суцвіть на } \\
\text { рослині, шт. }\end{array}$ & $\begin{array}{c}\text { Маса } \\
\text { кошика, } \mathbf{r}\end{array}$ & $\begin{array}{c}\text { Діаметр } \\
\text { кошика, см }\end{array}$ & $\begin{array}{c}\text { Маса пелю- } \\
\text { сток 3 1 суц- } \\
\text { віття, г (пові- } \\
\text { тряно-суха) }\end{array}$ & $\begin{array}{c}\text { Маса пелю- } \\
\text { сток 3 1 рос- } \\
\text { лини, г (пові- } \\
\text { тряно-суха) }\end{array}$ \\
\hline \multirow{3}{*}{ Teddy F1 } & 50 & 3,4 & 60,8 & 11,7 & 1,7 & 5,1 \\
\cline { 2 - 7 } & 60 & 3,1 & 44,2 & 8,0 & 1,5 & 4,7 \\
\cline { 2 - 7 } & 70 & 2,6 & 36,1 & 6,3 & 0,9 & 2,3 \\
\hline \multirow{3}{*}{ Double Sunking F1 } & 50 & 2,7 & 42,7 & 8,4 & 1,0 & 2,2 \\
\cline { 2 - 7 } & 60 & 2,2 & 32,3 & 7,2 & 0,6 & 1,3 \\
\hline \multirow{3}{*}{ Santa Fe F1 } & 70 & 1,8 & 18,1 & 5,5 & 0,5 & 0,9 \\
\cline { 2 - 7 } & 50 & 2,6 & 38,4 & 9,3 & 1,0 & 2,6 \\
\cline { 2 - 7 } & 60 & 2,3 & 32,0 & 7,3 & 0,7 & 1,6 \\
\hline
\end{tabular}

віття якого становила 47,0 г (від 60,8 до 36,1 г залежно від загущення посіву). Значення аналогічного показника за варіантом гібрида Double Sunking F1 було 31,0 г (від 42,7 до 18,1 г), за гібридом Santa Fe F1 - 30,2 г (від 28,4 до 20,2 г) (табл. 2).

Збільшення норми висіву зумовлювало також істотне зменшення діаметру суцвіть за всіма варіантами гібридів культури: даний показник у гібрида Teddy F1 зменшувався від 11,7 до 6,3 см за середнього значення 8,7 cм; Double Sunking F1 - від 8,4 до 5,5 см (7,0 см); Santa Fe F1 - від 9,3 до 6,0 см (7,5 см).

Габітус окремих суцвіть культури за варіантами досліду зумовив і диференційований характер такого показника, як збір повітряно-сухих пелюсток з одного кошика. Лідером за зазначеним показником у досліді відмічений також гібрид Teddy F1: за середнього значення 1,4 г продуктивність одного кошика гібрида зменшувалася від 1,7 до 0,9 г із збільшенням норми висіву від 50 до 70 тис. шт./га. Ця ж динаміка простежувалася нами і за рештою гібридів: Double Sunking F1 - 0,7 г (1-0,5 г); Santa Fe F1 - 0,8 г (1,0-0,6 г).

Отже, продуктивність окремих рослин (маса чоловічих пелюсток у повітряно-сухому стані, зібрана з 1 рослини) за варіантами фрактора А мала такий вигляд: гібрид Teddy F1 забезпечив отримання з однієї рослини в середньому 4,0 г фітосировини; гібрид Double Sunking F1 - 1,5 г, а гібрид Santa Fe F1 - 1,8 г. Оптимальною нормою висіву за всіма варіантами гібридів визнано норму 50 тис. шт./га, за якої продуктивність окремої рослини була максимальною і за варіантами фактора А становила відповідно 5,1, 2,2 та 2,6 г повітряно-сухих пелюсток, що в перерахунку на одиницю посівної площі становить 25,5, 11,0 та 13,0 кг/га фрітосировини в повітряно-сухому стані.

Висновки. Збільшення норми висіву культури з 50 до 70 тис. шт./га зумовлює погіршення значення більшості френологічних, біометричних та структурних показників (тривалість міжфразного періоду «сівба - сходи», фаза цвітіння та загальна тривалість вегетаційного періоду, кількість суцвіть на рослині, їх діаметр і маса, продуктивності). Характер зазначеної залежності встановлений як зворотний лінійний. У досліді відмічена істотна перевага за всіма показниками, що досліджува- лися, гібрида Teddy F1 порівняно з іншими варіантами фрактора A, а оптимальною нормою висіву культури визнана норма 50 тис. шт./га. Установлено, що за даних умов реально отримувати з одиниці посівної площі до 25,5 кг фрітосировини в повітряно-сухому стані.

\section{СПИСОК ВИКОРИСТАНОÏ ЛІТЕРАТУРИ:}

1. Жовтобрюх Н.В., Мельник А.В. Залежність тривалості цвітіння декоративного соняшника, вирощеного в горщиках в закритому ґрунті від діаметра суцвіття. Вісник Сумського національного аграрного універcumemy. 2004. Вип. 12. С. 88-89.

2. Мельник А.В. Визначення оптимального об'єму живлення і складу ґрунтосумішей при вирощуванні горщикової культури декоративного соняшника. Збірник наукових праць Уманського державного аграрного університету. 2005. № 61. T. 2. С. 559-563.

3. Методика проведення експертизи сортів соняшнику декоративного (Helianthus annuus L. ssp. ornamentalis) на відмінність, однорідність і стабільність URL: https://www.sops.gov.ua/uploads/ page/5b9240b9a2095.pdf.

4. Першин А.Ф., Першина И.М. Генетический потенциал декоративного подсолнечника. Цветоводство сегодня и завтра: ассортимент, технологии, маркетинг : материалы III-й Международной конференции, г. Москва. Москва, 1998. С. 210-213.

\section{REFERENCES:}

1. Zhovtobryukh N.V., Melnyk A.V. (2004), Zalezhnist' tryvalosti tsvitinnya dekoratyvnoho sonyashnyka, vyroshchenoho $v$ horshchykakh $v$ zakrytomu grunti vid diametra sutsvittya [Dependence of flowering duration of ornamental sunflower grown in pots in closed soil on the diameter of the inflorescence], Visnyk Sums'koho natsional'noho ahrarnoho universytetu, № 12. P. 88-89 [in Ukrainian].

2. Melnyk A.V. (2005). Vyznachennya optymal'noho ob'yemu zhyvlennya i skladu gruntosumishey pry vyroshchuvanni horshchykovoyi kul'tury dekoratyvnoho sonyashnyka [Determination of the optimal volume of nutrition and composition of soil mixtures in the cultivation of pot culture of ornamental sunflower], Zbirnyk naukovykh prats' Umans'koho derzhavnoho ahrarnoho universytetu, № 61. Ch. 2. P. 559-563 [in Ukrainian]. 
3. Metodyka provedennya ekspertyzy sortiv sonyashnyku dekoratyvnoho (Helianthus annuus L. ssp. ornamentalis) na vidminnist', odnoridnist' i stabil'nist'. Methods of examination of ornamental sunflower varieties (Helianthus annuus L. ssp. Ornamentalis) for difference, homogeneity and stability], https://www.sops.gov. ua/uploads/page/5b9240b9a2095.pdf [in Ukrainian].

4. Pershin A.F., Pershina I.M. (1998). Geneticheskiy potentsial dekorativnogo podsolnechnika [Genetic potential of ornamental sunflower], Materialy III-y mezhdunarodnoy konferentsii "Tsvetovodstvo segodnya i zavtra: assortiment, tekhnologii, marketing", Moscow, Main bot. garden RAS [in Russian]

\section{Жуйков О.Г., Лаврись В.Ю. Норма висіву насіння} як фактор формування продуктивних та господарсько цінних ознак гібридів соняшнику багатоквіткового за органічної технології вирощування в Південному Степу

Мета дослідження - проведення конкурсного випробування сучасного гібридного складу культури, його еколого-господарське обґрунтування, а також установлення оптимальної норми висіву. На вивчення були винесен такі елементи фенолого-біометричного та структурного характеру: тривалість вегетаційного періоду й окремих міжфазних періодів культури, висота рослин декоративного соняшнику, виживання рослин упродовж вегетації, кількість квітучих кошиків на рослині, діаметр кошика, маса пелюсток з одного суцвіття та з однієї рослини. Методи. Реалізацію поставленої наукової мети було здійснено закладанням і проведенням двофакторного польового досліду, у якому фактором А виступав гібрид культури (Teddy F1, Double Sunking F1, Santa Fe F1), а фактором B - норма висіву культури (50, 60 та 70 тисяч штук схожих насінин на 1 гектар). Результати. У досліді істотно виділявся гібрид Teddy F1, тривалість утворення фрази повних сходів якого з момента сівби була найменшою з-поміж інших варіантів фрактора А і становила 6 діб, що на 4 та 5 діб менше, ніж у варіантах гібридів Double Sunking F1 та Santa Fe F1. Збільшення норми висіву зумовлювало також істотне зменшення діаметра суцвіть за всіма варіантами гібридів культури: даний показник у гібрида Teddy F1 зменшувався від 11,7 до 6,3 сантиметрів за середнього значення 8,7 сантиметрів; Double Sunking F1 - від 8,4 до 5,5 сантиметрів (7,0 сантиметрів); Santa Fe F1 - від 9,3 до 6,0 сантиметрів (7,5 сантиметрів). Габітус окремих суцвіть культури за варіантами досліду зумовив і диференційований характер такого показника, як збір повітряно-сухих пелюсток з одного кошика. Лідером за зазначеним показником у досліді відмічений також гібрид Teddy F1: за середнього значення 1,4 грам продуктивність одного кошика гібрида зменшувалося від 1,7 до 0,9 грама зі збільшенням норми висіву від 50 до 70 тисяч штук на гектар. Ця ж динаміка простежувалася нами і за рештою гібридів: Double Sunking F1 - 0,7 грама (1-0,5 грама); Santa Fe F1 - 0,8 грама (1,0-0,6 грама). Продуктивність окремих рослин (маса чоловічих пелюсток у повітряно-сухому стані, зібрана з 1 рослини) за варіантами фрактора A мала такий вигляд: гібрид Teddy F1 забезпечив отримання 3 однієї рослини в середньому 4,0 грами фрітосировини; гібрид Double Sunking F1 - 1,5 грама, а гібрид Santa Fe F1 - 1,8 грама. Висновки. Оптимальною нор- мою висіву за всіма варіантами гібридів визнано норму 50 тисяч штук на гектар, за якої продуктивність окремої рослини була максимальною і за варіантами фактора А становила 5,1, 2,2 та 2,6 грами повітряно-сухих пелюсток відповідно, що в перерахунку на одиницю посівної площі становить відповідно 25,5, 11,0 та 13,0 кілограмів на гектар фітосировини в повітряно-сухому стані.

Ключові слова: соняшник багатоквітковий, гібриди, густота стояння, органічна технологія вирощування, тривалість періоду вегетації, структурні показники врожайності, врожай фітосировини.

Zhuikov O.G., Lavrys V.Yu. Seed sowing rate as a factor in the formation of productive and economically valuable traits of multi-flowered sunflower hybrids by organic cultivation technology in the Southern Steppe

The purpose of the study is to conduct a competitive test of modern hybrid composition of culture, its ecological and economic justification, as well as to establish the optimal seeding rate. The following elements of phenologicalbiometric and structural nature were studied: duration of vegetation period and separate interphase periods of culture, height of ornamental sunflower plants, survival of plants during vegetation, number of flowering baskets per plant, basket diameter, weight of petals from one inflorescence and one plant. The realization of this scientific goal was carried out by establishing and conducting a twofactor field experiment, in which factor $A$ was a hybrid culture (Teddy F1, Double Sunking F1, Santa Fe F1), and factor $B$ - seeding rate $(50,60$ and 70 thousand pieces of similar seeds per 1 ha).

The Tiddy F1 hybrid was significantly distinguished in the experiment. Santa Fe F1. The increase in seeding rate also led to a significant decrease in the diameter of inflorescences in all variants of culture hybrids: this figure in the hybrid Teddy $\mathrm{F} 1$ decreased from 11,7 to $6,3 \mathrm{~cm}$ with an average of $8,7 \mathrm{~cm}$; Double Sunking $\mathrm{F} 1$ - from 8,4 to $5,5 \mathrm{~cm}(7,0 \mathrm{~cm})$, respectively; Santa Fe $\mathrm{F} 1$ - from 9,3 to $6,0 \mathrm{~cm}(7,5 \mathrm{~cm})$. The habit of individual inflorescences of the culture according to the variants of the experiment also determined the differentiated nature of such an indicator as the collection of air-dry petals from one basket. Teddy F1 hybrid was also the leader in this experiment: with an average value of $1,4 \mathrm{~g}$, the productivity of one basket of hybrid decreased from 1,7 to $0,9 \mathrm{~g}$ with an increase in seeding rate from 50 to 70 thousand units / ha. The same dynamics was followed by us for other hybrids: Double Sunking F1 - 0,7 g (1-0,5 g); Santa Fe F1 - 0,8 g $(1,0-0,6 \mathrm{~g})$. Productivity of individual plants (mass of male petals in the air-dry state, collected from 1 plant) according to the factors of factor $A$ was as follows: hybrid Teddy $\mathrm{F} 1$ provided a single plant, on average, $4,0 \mathrm{~g}$ of phyto raw materials; hybrid Double Sunking F1 - respectively $1,5 \mathrm{~g}$, and hybrid Santa Fe F1 1,8 g. The most optimal sowing rate for all variants of hybrids is the rate of 50 thousand units / ha, at which the productivity of an individual plant was maximum and according to variants of factor $A$ was, respectively, 5,$1 ; 2,2$ and $2,6 \mathrm{~g}$ of air-dry petals, which per unit of sown area is, respectively, 25,5; 11.0 and $13,0 \mathrm{~kg} /$ ha of phyto raw materials in the air-dry state.

Key words: multi-flowered sunflower, hybrids, stocking density, organic cultivation technology, duration of the growing season, structural yield indicators, phyto raw material yield. 